Pamiętnik Literacki 2014, 3, s. 111-128
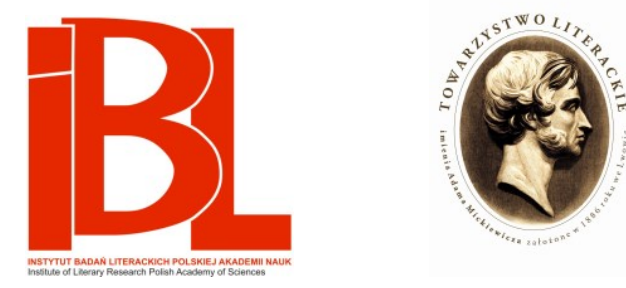

\title{
Jerzy Andrzejewski - katastrofy ciała i odmowa sublimacji
}

\author{
Wojciech Śmieja
}




\section{JERZY ANDRZEJEWSKI - KATASTROFY CIAŁA I ODMOWA SUBLIMACJI*}

Jerzy Andrzejewski na pozowanych fotografiach lubi przybierać intelektualne pozy. Lubi, gdy w tle widać jego bibliotekę. Często fotografuje się z papierosami, ale nie są to papierosy robociarza, raczej już Gauloises, takie jak u Jeana-Paula Sartre'a. Kiedy tylko kończy z socrealizmem, pisarz zarzuca szarobure garnitury na rzecz niezobowiązującej „sportowej” elegancji. Ci, którzy się z nim zetknęli, zwracają uwagę, że Andrzejewski bardzo dbał o swój wygląd i strój, że zarówno ta dbałość, jak i przemyślany sposób ubierania się wyróżniały go z szaroburej gomułkowskiej rzeczywistości. Andrzej Mencwel pyta:

Jaki był Jerzy Andrzejewski? Pierwsze określenie, jakie mi się nasuwa, jest nieoczekiwane: przystojny. Kiedy go poznałem osobiście i się z nim zbliżyłem, [...] kończył już sześćdziesiątkę, ale tr zy m ał się młodzieńczo. Ubierał się też młodzieńczo, choć nie $\mathrm{w}$ dżinsy, lecz w jakieś wąskie spodnie z płótna lub alpaki, które przywoził sobie z Paryża i lubił się nimi chwalić, do tego swetry, lekkie marynarki, żadnych trzyczęściowych garniturów, krawat od wielkiego dzwonu.

Na smukłej sylwetce, którą nosił bocianim trochę krokiem długich nóg, a którą wyraźnie lubił i na którą lubił też zwracać uwage, żartobliwie, $\mathrm{z}$ autoironią, osadzona była głowa [...].

Właściwie chciałoby się powiedzieć, że był brzydalem, choć to nieprawda, bo nazywać tak można statyczny obraz, jaki tu staram się wywołać, a Jerzy zawsze był ruchliwy, migotliwy, wielopostaciowy ${ }^{1}$.

Sięgając do relacji z przedwojnia, zobaczymy, że inaczej niż w latach sześćdziesiątych i siedemdziesiatych XX wieku, kiedy pisarz się odmładzał, w latach trzydziestych szukał sposobu na „postarzenie się”:

Ani przez pięć minut nie wierzyłem w katolicyzm Jerzego Andrzejewskiego, a po przeczytaniu kilku stronic jego powieści powitałem w kawiarni Zodiak jego cierpiętniczą i uduchowioną twarz miną tak wątpliwą, iż obrażony autor natychmiast zerwał ze mną stosunki².

W szeroko cytowanej relacji Czesława Miłosza to upozowanie autora Ładu serca na starszego łączy się z obsesją czystości:

* Tekst powstał w ramach projektu badawczego Narodowego Centrum Nauki Maestro 4 zatytułowanego Męskość w literaturze i kulturze polskiej XIX i XX wieku (nr 2013/08/A/HS2/00058), realizowanego na Uniwersytecie Śląskim w Katowicach.

1 A. M e n c w e 1, O Jerzym Andrzejewskim. Jerzy wielopostaciowy. „Gazeta Wyborcza” 2010, nr z 17 V. Na stronie: http://wyborcza.pl/1,76842,7885872,O_Jerzym_Andrzejewskim_Jerzy_wielopostaciowy.html (dostęp: 26 II 2014). Podkreśl. W. Ś.

2 W. Gombrowicz, Dziennik 1953-1956. Oprac. Z. Górzyna. Uwagi interpretacyjne J. Jarzęb ski. Kraków 1986, s. 21. 
Alfa przed drugą wojna światowa był to wysoki, chudy młodzieniec w rogowych okularach. [...] potrzeba czystości, powiedziałbym nieziemskiej czystości, była cechą charakteru Alfy, który w obcowaniu z ludźmi lubił być wyniosły i chodzić na koturnach. [...] Ktoś o nim powiedział, że zanim weźmie do ręki pióro, nakłada powłóczystą szatę maga [...]. Godnością, która by mogła nasycić jego ambicję, była godność kardynała. Powolne ruchy, purpura, podawanie pierścienia do pocałowania - oto czystość gestu, wyładowanie się w lepszym ja [... $]^{3}$.

Jeszcze w czasie wojny ,jego wysoki wzrost, chudość, ironiczne błyski oczów zza okularów i namaszczenie, z jakim kroczył ulicami miasta [...], składały się na sylwetkę zaprzeczająca prawom wojny"4.

Można by zapytać: czy wzorem Doriana Graya podpisał Andrzejewski jakiś cyrograf i miast niego starzał sie jego portret? Nic z tych rzeczy - najbliższa jego przyjaciółka, Irena Szymańska, na początku lat sześćdziesiątych ubiegłego wieku notuje przedwczesne i ulokowane w ciele obawy autora Miazgi: „Ma dopiero 53 lata, ale już nęka go obsesja starzejącego się ciała"5. Chęć podobania się i odmładzanie się - to dla ludzi, ale dla siebie gorzkie refleksje $z$ tamtego okresu, a nawet, jak chciałaby Szymańska, obsesja.

Ze wstrętem patrzę na siebie w lustro. Jakaż głupia i straszna przewrotność natury i umysłu: im więcej przybywa mi zmarszczek na twarzy, im obrzydliwiej flaczeje moje ciało i włosy im bardziej mi siwieją i przerzedzają się, tym gwałtowniej wzbiera we mnie ślepe pożądanie młodości ${ }^{6}$.

Poczucie wstrętu do samego siebie, do własnego ciała zdaje się w pisarzu narastać wraz z wiekiem, choć, mam wrażenie (o czym dalej), że narodziło się dość wcześnie, wcześnie też zyskało literacki wyraz (jeśliby przyjąć, iż pewne rysy sylwetki księdza Siechenia z Ładu serca sa projekcją atrybutów autora). Motyw zniechęcenia do własnego ciała, podkreślanie jego brzydoty, często wraca na stronicach diariusza Andrzejewskiego: „Czując pogardę i wstręt do ciała własnego - nie sposób pragnąc ciał innych”, zauważa zniechęcony pisarz w drugim tomie swojego dziennika literackiego ${ }^{7}$.

Badacze dawno już dostrzegli, jak duże ma znaczenie - w twórczości autora Miazgi - ciało i wyobrażenie z nim związane: „Idea, tak zawsze sądził Andrzejewski, wszczepia się w ciało i krew, nic dziwnego zatem, że fizjologia najwcześniej sygnalizuje gotujący się przełom" 8 - zauważyła Maria Janion. W podobnym tonie pisał też Dariusz Nowacki, gdy podkreślał, iż współczesny czytelnik Andrzejewskiego „stoi przed zadaniem opowiedzenia nieopowiedzianej historii- his torii politycznej i historii ciała"9. Ani jednak Janion, ani Nowacki nie wychodzą właściwie poza te stwierdzenia - zadanie wciąż jest nie odrobione. W pro-

3 Cz. Mił o s z, Zniewolony umyst. Kraków 2004, s. 72-73. Podkreśl. W. Ś.

Ibidem, s. 77.

5 I. Szy mań s ka, Miałam dar zachwytu. Wspomnienia wydawcy. Zebrał i oprac. R. Mat u s ze ws ki. Warszawa 2001, s. 196.

6 Cyt. za: A. Synoradzka, Andrzejewski. Kraków 1997, s. 139. Literacką transpozycją tych zapisów osobistych są fragmenty Miazgi.

7 J. An d r zej e w s ki, Z dnia na dzień. Dziennik literacki 1972-1979. T. 2. Warszawa 1988, s. 468.

$8 \quad$ M. J anion, Wobec zła. Chotomów 1989, s. 119.

9 D. N ow a c ki, „Ja” nieuniknione. O podmiocie pisarstwa Jerzego Andrzejewskiego. Katowice 2000, s. 120. 
ponowanym tu szkicu postaram się zasugerować pewne rozwiązania, opowiedzieć "historię ciała”.

Fragmenty dzienników i wspomnień Andrzejewskiego publikowane jeszcze za jego życia zaskakują otwartością, z jaką pisarz mówi o doświadczeniach i sferach intymnych, prywatnych, kulturowo stabuizowanych. Nie uchyla sie przed swego rodzaju skatologicznym ekshibicjonizmem, zupełnie nie licującym $z$ kardynalska godnością imputowaną mu przez Miłosza. Czystość i brud splatają się szczególnie w autorskich Notatkach do autobiografii (1909-1924) w iście szatański węzeł - „potrzeba czystości Alfy" napotyka tu dialektyczne przeciwieństwo: s kala ni e. Oto fragment wspomnień z 1916 r. (Andrzejewski ma wtedy 7 lat):

[...] Lutek, długonogi brunecik [...], zbliżał się do mego wieku, był starszy o rok lub dwa. [...] Był silniejszy, szybszy, fizycznie dojrzalszy aniżeli ja, nie miałem w sobie nic $z$ jego zuchwalstwa i upodobania do bijatyk. Trochę mi imponował i trochę odstręczał. Chyba nigdy przedtem, a i nigdy potem moja chłopięca męskość nie starła się tak blisko i na co dzień z żywiołem chłopięcości równie odmiennym.

Pamiętam: dość często, bodaj co tydzień, chodziliśmy do łaźni [...]. Czarnowłosego i smagłego bawiła białość mego ciała, mógł się też chełpić, że jego siusiak lepiej się prezentuje aniżeli mój, szczególnie w wodzie, gdy u mnie się kurczył, a u niego, skoro się z tej wody wychylał - przeciwnie. [...] Skoro zaś znalazłem się wreszcie obok, rozgrzany i mokry, ze swawolnym ognikiem w brązowych oczach, chwytał mnie za przeguby rąk, przyciagał do siebie i mocnym uchwytem w pasie lub poniżej ramion zmuszał do siłowania. Nie wykluczam, że te zmagania w wannie mogły mieć dla mnie pewien urok, a cielesna bliskość stryjecznego brata nie była mi niemiła. [...] Lutek wiedział, że mnie pokona, ja - że ulegnę, obaj znaliśmy swoje myśli [...]. Czasem, by nierówne zapasy skrócić, ulegałem prawie natychmiast, ale Lutek nie lubił kapitulacji łatwej i szybkiej, więc gdy przedwcześnie w jego ramionach wiotczałem, stawał się agresywny i brutalny, rozmyślnie zadawał ból [...], początkowe igraszki przekształcały się w bójkę. [...] świadomy, że nie lubię mokrych włosów [...], chwytał mnie za kark i zmuszał do zanurzenia głowy, dając mi spokój wtedy dopiero, gdy zaczynałem się krztusić i rozpaczliwie bulgotać. Miał wszystkie racje, żeby czuć się tryumfatorem, dawał też temu wyraz [...]: stał rozkraczony na całą szerokość wanny, z dłońmi wspartymi o zwięzłe biodra, jego błyszczące oczy i rozchylone w uśmiechu usta [...] aż nadto wyraźnie mówiły: popatrz, popatrz, jaki ja jestem! Podbrzusze, w przeciwieństwie do mojego nagiego jak pupka, miał już pociemniałe, chłopięcy ptaszek prowokująco duży, i co mnie przyprawiało o lękliwie, a także i zazdrośnie zdziwiony niepokój: samodzielnie żywy, bo wbrew nieruchomości ciała poruszał się, wyprężał, podnosił i opadał, nie wiadomo skąd i przy pomocy jakich sztuczek osiagając suwerenną niezależność. [N 191-193; podkreśl. W. Ś.] $]^{10}$

Dłuższa ta sekwencja, jak również kolejne fragmenty Notatek do autobiografii (1909-1924), które będę tu omawiał, muszą być odniesione do szerszego kontekstu tomu, w jakim się ukazały. Nowe opowiadania Andrzejewskiego nie trafiły w swój czas, odbiorcy nie dostrzegli niezwykłości książki, która do dziś nie budzi też większego zainteresowania „andrzejewskologów”. Złożyło się na to kilka przyczyn - po pierwsze, najnowsza wtedy twórczość Andrzejewskiego jakby się rozmijała z czytelniczymi oczekiwaniami; recenzenci i krytycy niewiele uwagi poświęcali nowym tekstom, a większość spośród recenzji mało była przychylna autorowi Popiołu i diamentu. To, na co czytelnicy czekali i co wzbudzało wielkie nadzieje pisarza, to,

10 Skrótem N odsyłam do: J. An drzej ew s ki, Nowe opowiadania. Warszawa 1980. Ponadto stosuję skrót do powieści tego samego autora: $€=$ Ład serca. Warszawa 1957. Liczby po skrótach wskazuja stronice. 
oczywiście, publikacja Miazgi (1979, 1982), która swoim gatunkowym ciężarem i epickim rozmachem zdawała się przytłaczać wszystko inne. Na tę czytelniczą obojętność wpływ też miały prawdopodobnie kwestie pozaliterackie - nikomu chyba nie trzeba przypominać, czym głowy Polaków zajęte były w 1980 roku... ${ }^{11}$

Mimo to dziwi fakt, że przynajmniej niektóre $z$ utworów ${ }^{12}$ nie wywołały skandalu literackiego i obyczajowego. Oto bowiem w Notatkach do autobiografii (19091924) ${ }^{13}$ Andrzejewski opowiada - jak już widzieliśmy, dość obcesowo - o swoich młodzieńczych erotycznych przeżyciach $z$ kuzynem Lutkiem ${ }^{14}$, o spleceniu erotyzmu z okrucieństwem, a dalej snuje parazytologiczne rozważania o nękających go owsikach i wszach łonowych, aż wreszcie zwierza się z traumatycznego i skatologicznego epizodu w swoim życiu. Ekshibicjonistyczne passusy ukazujące przyjemności masochistyczne $\mathrm{w}$ połączeniu ze skatologicznymi wspomnieniami współbrzmia z tonem większości pomieszczonych w tomie tekstów, w których kategorie czystego/ nieczystego stanowią nierzadko element strukturujacy przedstawioną (i nasyconą relacjami przemocy) rzeczywistość: w Pierwszej miłości, otwierającej zbiór opowiadań, chłopiec „przerabia” dziewczynkę w chłopca, co dokonuje się m.in. przez to, że zaznajamia jego/ja z tym, czym jest oksymoroniczny „czysty brud” (N 11, 13). Następny tekst, W Dzień Zwycięstwa wieczorem, mówi o bójce dwóch głuchoniemych mężczyzn, którzy zwierają się w bezrozumnej walce w momencie, gdy całe miasto grzmi od salw obwieszczajacych pokonanie hitlerowskich Niemiec. Opowiadanie Ciemna gwiazda to utwór dość jawnie autobiograficzny i homoerotyczny, aż proszący się o rozszyfrowanie personalnego klucza. Złączony z erotyzmem temat brudu powraca $w$ nim jako wyznanie jednego $z$ bohaterów - Stasia, który „w trakcie rozmowy o Tomaszu Mannie [...] nagle, bez żadnego związku z tematem naszej dyskusji, oświadczył, że po stosunku z dziewczyną musi wziąć tusz [...]" (N 60) ${ }^{15}$. Kolejne opowiadanie - jedno $\mathrm{z}$ najmroczniejszych, jakie Andrzejewski napisał, noszące tytuł Po tamtej stronie - stanowi diaboliczną mieszankę przemocy, koprofagii,

11 Należy dodać, że ukazanie się Nowych opowiadań w 1980 r. stało się możliwe także dzięki zelżeniu cenzury. Biografka pisarza, Syn or a dzk a (op. cit., s. 176), przypomina, że „w roku 1976 Andrzejewski postanowił opublikować zbiór zawierający kilka nie drukowanych utworów napisanych jeszcze w latach sześćdziesiątych oraz parę dzieł najnowszych. Tomik Nowe opowiadania złożony w "Czytelniku" nie otrzymał zgody na rozpowszechnianie. Było to wynikiem wymowy ideologicznej kilku zawartych w zbiorze tekstów (Wyznanie osobiste, Msza za poetę zmartego na emigracji), ale z pewnością także represją za pozaliteracką działalność autora”.

12 Tytuł Nowe opowiadania wydaje się nieadekwatny, gdyż oprócz 6 opowiadań w tomie znajdziemy również 3 teksty nie spełniające genologicznych kryteriów opowiadania: esej wspomnieniowy, odczyt, fragmenty autobiografii.

13 Stanowią one znacznie rozszerzoną, nową wersję Ksiażki dla Marcina z r. 1954, w której jednak cytowanych tu i komentowanych fragmentów nie było. Zob. Z. Ko p e ć, Jerzy Andrzejewski. Poznań 1999, s. 153.

14 Jeśliby przyjąć za dobrą monetę opinię No w a c k i e go (op. cit., s. 107), że autobiografizm Andrzejewskiego jest fingowany i ułożony z „cudzego słowa”, to oczywistym kontekstem opowiadanej przez niego historii erotycznych urzeczeń jest J. Iwaszkiewicza pławienie koni z Książki moich wspomnień (Warszawa 1975, s. 111-112). Andrzejewski jednak znacznie dosadniej i bardziej bezpośrednio omawia przeżycia, które w Iwaszkiewiczowskim opisie ulegają daleko idącej idealizacji.

15 Dodajmy, że Staś to homoseksualista, natomiast jego partnerka jest androgyniczna, dominująca i podporządkowuje sobie dość zniewieściałego Stasia. 
homoseksualizmu i szaleństwa. W Wyznaniu osobistym, kolejnym tekście zbioru, naszą uwagę zwraca autodeskryptywne zdanie:

Żona moja twierdzi, że swego czasu znacznie lepiej znosiłem bombardowania i stan osobistego zagrożenia niż kurz na biurku albo zapachy kuchenne przenikające do pokojów. A choć brzmi to może nieco groteskowo i niemal niewiarygodnie, mam wrażenie, że istotnie tak właśnie ze mną było i jeszcze jest. [N 134]

W dalszej zaś części Wyznania osobistego Andrzejewski porównuje pisanie do zanieczyszczonej rzeki Hudson, a wreszcie do pracy skarabeusza lepiącego kulkę łajna (N 140-143). Kolejnym tekstem znajdującym się w tomie są właśnie Notatki do autobiografii (1909-1924), ku którym autor prowadzi nas tymi słowy:

Do spisywania notatek przystapiłem z myślą, iż będą opublikowane i czytane, jednak inspiracją silniej pobudzającą u początku i w trakcie pracy była moja kondycja osobista, cokolwiek rozchwiana i mętna. [N 145]

Wyposażeni w tę wiedzę o całości zbioru opowiadań Andrzejewskiego, wróćmy do cytowanego fragmentu Notatek do autobiografii (1909-1924). Mówiąc o quasi-erotycznych zbliżeniach z kuzynem, buduje pisarz ciąg opozycji zastępczych. Prymarna jedność płci bohaterów i bliskość rodzinna zostają zneutralizowane antynomia konstytuowaną poprzez opozycje siła/słabość, dojrzałość/niedojrzałość, aktywność/bierność, później także wiejskość/miejskość. Najciekawsza wydaje się wszakże różnica niemal kastracyjna. Członek młodego Andrzejewskiego właściwie nie istnieje - kurczy się w wodzie i jest „nagi jak pupka [...]”, podczas gdy członek kuzyna tężeje w wodzie, a ponadto jest „prowokująco duży [...]”, niepokojacy, bo „samodzielnie żywy [...]”, „wbrew nieruchomości ciała poruszał się, wyprężał, podnosił i opadał, nie wiadomo skąd i przy pomocy jakich sztuczek osiagając suwerenną niezależność". Absolutną bierność i pasywność - ośmielę się nawet powiedzieć (upoważnia mnie do tego skojarzenie „ptaszka” z „pupka”), że a n a ln o ś ć - zestawiono $\mathrm{z}$ nadzwyczajną aktywnością, hiperaktywnością: kuzyn w pewnym sensie sam jest fallusem, jeden i drugi wyprężają się dumnie nad „ulegającym” i „wiotczejącym" Andrzejewskim. Wzwiedziony członek Lutka promieniuje na resztę ciała, wydaje się tak ożywiony, że niemal z niego się wyrywa. Nie musimy mieć wielkiej wyobraźni, by domyślić się jego penetracyjnej mocy! Bardziej przeczuwana niż wyobrażana, sprawia ona, iż w podmiocie mieszają się emocje: fascynacja i przerażenie, Lutek doświadcza też sadystycznej przyjemności podczas zbliżenia się obu ciał w bójce. A oto dalszy ciąg wyznania:

Dzięki niezbyt skomplikowanym skojarzeniom przychodzi mi w tej chwili na myśl (29 V 1972), że towarzysko-intelektualna dialektyka Witolda Gombrowicza, świadomie i z maniakalnym uporem stosowana przez niego w zetknięciu z ludźmi, choć na wyższych kondygnacjach rozeznania ulokowana w podstawowych zasadach mechanizmu podobna była, jeśli nie identyczna, do cielesnych gier, praktykowanych przez mego dziewięcioletniego kuzynka dla zaspokojenia jego potrzeb własnych, lecz ze mną i przeciwko mnie. [N 193; podkreśl. W. Ś.]

Niewiarygodny to przeskok - młodzieńcza opowieść z łaźni przekłada się bezpośrednio na literacko-towarzyskie perypetie pisarza, prefiguruje dręcząca go 
w wieku dojrzałym relację $z$ Gombrowiczem ${ }^{16}$. Bo trzeba dodać, że fakt, iż autor Pornografii zostaje obsadzony w roli kuzyna-dręczyciela, oznacza, że dorosły Andrzejewski obsadza się w roli podmiotu-dręczonego, więc i emocje, jakich doświadcza, są w swoim zasadniczym rysie tożsame $\mathrm{z}$ emocjami doznawanymi w łaźni: pragnienie, upokorzenie, podziw i niechęć. A także rozbicie wewnętrzne wreszcie, bo wszystko to, jak powiada narrator: „ze mną i przeciwko mnie”. Agresywny popęd skierowany przeciwko samemu sobie nosi nazwę masochizmu i z masochistycznej przyjemności/przykrości Andrzejewski zdaje nam tu sprawę. Przywoływane i powtarzające się (by nie powiedzieć: persewerowane) seanse odbywane $z$ Lutkiem w łaźni określają więc pewien modus funkcjonowania dorosłego pisarza względem przynajmniej niektórych innych mężczyzn, reprezentowanych tu przez Gombrowicza, znanego z upodobania do poniżania Andrzejewskiego.

Wróćmy jednak do tekstu i zdarzeń w łaźni:

zawieszenie broni obowiązywało wówczas dopiero, gdy starszy i silniejszy [Lutek], nasycony własnym zwycięstwem i moją porażką, uznał, iż trzeba się namydlić i brud spłukać, chyba instynkt chłopskich przodków odzywał się w nim w tym kulminacyjnym, obrzędowym momencie kapieli. Po skupionych ablucjach szybko odzyskiwał swobodę. Spór wynikał natychmiast, gdy opuszczaliśmy wannę. Lutek nie korzystał z ręcznika, nie lubił się wycierać [...]. Ja natomiast nie cierpiałem wilgoci pod odzieżą, nawet tak lekką i przewiewna jak letnia. Niestety, rzadko kiedy udawało mi się dokładniej wytrzeć. Lutek wydzierał mi ręcznik, a gdy usiłowałem wyschnąc w sposób naturalny - na roścież otwierał drzwi kabiny. Tak więc, daleki od dziarskiego ożywienia, opuszczałem budynek kapielowy brudniej s zy we własnym samopoczuciu aniżeli przedtem, nawilgły trykocik niczym obustronny kompres ziębił mi piersi i plecy, mokro i klejko miałem w kroku, uroda moich włosów była sponiewierana, nie mogłem odczuwać zadowolenia, nie mogłem siebie lubić. [N 193-194; podkreśl. W. Ś.]

Skutkiem kapieli jest zatem skala nie, przynajmniej psychiczne, i brak akceptacji samego siebie, poczucie sponiewierania. Materialny nośnik tego brudu stanowi woda, którą ocieka ciało chłopca. Udobitnione zostało to, co odczuwane w kroczu: tam jest nie tylko „mokro”, ale i „klejko” - śluzowato. Jeden z tych łaziebnych seansów zakończył się dla Andrzejewskiego szczególnie mocnym skalaniem:

Pewnego razu [...], gdy wracaliśmy z kapieli i jeszcze się znajdowaliśmy na terenie cukrowni, Lutek nagle pchnął mnie w bok i nim się zorientowałem, moje bose stopy [...] ugrzęzły w gę s tej i le pki ej mazi, była to smoła już nie gorąca, lecz jeszcze nie stwardniała. To było okropne i obrzydliwe: żwir, piasek i kurz przylepiały się do moich czarnych kopytek, nie chciałem się w takim stanie pokazać w domu, więc przy napotkanej po drodze studni próbowałem obmyć s paskudzon e stopy, daremne były jednak moje wysiłki, dość gruba i zesztywniała warstwa smoły okazała się odporna na zimną wodę, siedziałem zatem przy studni osowiały, z mokrą moją piastowsko-pacholęca głową, tępo wpatrzony w błotnistą kałużę [...], Lutek coś mówił i mówił, wreszcie się zniecierpliwił, machnął ręką i poszedł.

Co robiłem potem i kiedy wróciłem do domu - nie pamiętam, mogłoby to świadczyć, że skoro człowiek, nawet małoletni, posiada oprawcę, on przede wszystkim jest ważny, nie - ofiara. [N 194; podkreśl. W. Ś.]

Upatrywanie w tej scenie jakiegoś rodzaju „sceny pierwotnej” i rozpoznanie 
w niej bezpośrednich odniesień do twórczości byłoby dość naiwnym biografizmem, niemniej fakt wydaje się interesujący, że owa scena to kolejna scena w przywoływanej sekwencji kończąca się uogólnieniem - w pierwszej scenie tyczyło ono relacji z Gombrowiczem, w obecnej zaś wiąże się $z$ ambiwalencją: ofiara/oprawca. Smoła, w którą Lutek wtrąca Andrzejewskiego, skojarzona jest z nieczystością, z błotem, a może nawet i gównem (smołę i kał utożsamia polszczyzna, wszak pierwsze stolce niemowlęcia to właśnie smołka). Brud, którym zostały wymazane stopy Andrzejewskiego, zamienia je w kopytka. Skalanie smoła, do jakiego doszło, wiąże się $z$ ostatecznym ubrudzeniem ofiary: ofiara jest brudna, bo jest ofiara, i jest ofiara, bo jest brudna.

Wysmarowanie smołą/kałem stóp podmiotu stanowi sataniczne (smoła to przecież materia diabelska) odwrócenie sakramentu bierzmowania, w którym szafarz namaszcza krzyżmem czoło wiernego, by poświadczyć jego osiagnięcie stanu dojrzałości religijnej.

Od tego s ka la nia, które z pozoru wyniknęło przypadkowo w trakcie zabawy, a w rzeczywistości stanowiło (retroaktywnie) rodzaj bluźnierczego sakramentu, Andrzejewski już nigdy się nie wyzwoli, ma - przywołajmy choćby cytowane tu Wyznanie osobiste - obsesję czystości, ale im obsesyjniej chce być czysty, tym bardziej okazuje się skalany, a przynajmniej tak sam siebie postrzega. Oto bowiem kilkadziesiąt stronic dalej wyznaje:

Od pewnego czasu cierpiałem na dolegliwość mało poważną, lecz złośliwie dokuczliwą: ulokowały się we mnie robaki, tzw. owsiki. Ta minichoroba, prawie nagminna w wieku dziecięco-chłopięcym, wielokrotnie miała się we mnie zagnieżdżać, jeszcze w latach pełnej męskości stawałem się obiektem szczególnie przewlekłej inwazji tych drobnych i, kosztem of i a ry, w której się zagospodarowuja, dobrze wypasionych robaków. W ogóle przez całe prawie życie, jakby w od wet za wrodzon a p ot rzebę czystości, robactwo oraz owady napastliwie kasajace bardzo mnie lubiły. Szczególnie pchły lgnęły do mnie z namiętną miłością, skakały na mnie wszędzie i przez cały okragły rok bywało, że całe ciało miewałem pokryte nieznośnie swędzącymi bąblami. Na dobrą sprawę dopiero od kilku lat zaniechały mnie, widocznie już ich nie p o cią ga zapach mojej skóry i nie smakuje im moja krew. Zdaje się, że starzejącym się ciałem tylko mendy nie gardzą. [N 209; podkreśl. W. Ś.]

Brud (robaki i pasożyty jako znaki nieczystości) łączy się tu znowu z seksualnością, a ściślej mówiąc - ze sferami erogennymi: odbytem i genitaliami. Jeden podgryzany przez owsiki, drugie kąsane przez mendy. Oczywiście, trudno dociec, na ile rzeczywiście narratora ponadstandardowo nękały pasożyty, na ile zaś nękanie to było forma projekcji, tak jak wcześniej projekcją było skalanie wodą. Przytoczona deklaracja, bez względu na to, czy odzwierciedla istotę rzeczy czy też nie, stanowi swego rodzaju autodenuncjację i przejaw samoponiżenia: pisarz - autorytet moralny, mówi o najintymniejszych przeżyciach, choć nie tak dawno na stronicach opowieści Idzie skaczac po górach oraz, jeszcze wyraźniej, w utworze Już prawie nic denuncjował i krytykował wścibstwo dziennikarzy, dla których znaczenie ma nie dzieło Antonia Ortiza czy Hermana Eisbergera, lecz właśnie sekrety ich osobistego życia i alkowy. Opowiadana w Notatkach do autobiografii (1909-1924) prywatność jest właściwie intymnością, i to intymnością silnie w europejskiej kulturze stabuizowaną. Andrzejewski dobrowolnie dopuszcza nas tam, gdzie nawet najbardziej wścibscy żurnaliści nie są skłonni zaglądać... 
Zwróćmy również uwagę, że pisarz opowiadając o tych wstydliwych dolegliwościach znowu sytuuje się - expressis verbis - w roli ofiary. Wraz z tą autodeskrypcją powraca dynamika przemocy znana nam już z laziebnych spotkań z Lutkiem. Nie dziwi zatem fakt, że o pasożytach mówi Andrzejewski językiem miłości i pożądania, bo - dziwnym trafem - ta dziecięca przypadłość gnębi pisarza także w dorosłym życiu, a więc wtedy, gdy nasza seksualność jest już najczęściej w pełni ukształtowana, a owsiki raczej nam nie doskwierają. Oczywiście, potocznie również mówimy np., że komar lu b i czyjąś krew, lecz Andrzejewski te emocje hiperbolizuje, przez co język wspomnienia daleko wykracza poza potoczność i staje się perwersyjny: owady „lgną z namiętną miłością [...]”, zapach skóry „pociaga je” (potocznie mówi się raczej, że przyciaga), w ostateczności starym ciałem „nie gardzą” już tylko wszy łonowe (mendy - i wyłącznie mendy - wciąż go pragna), gdyż inne pasożyty właśnie nim (starym ciałem pisarza) wzgardziły! ${ }^{17}$ Zapewne ukształtowanie fragmentu i hiperbolizacja języka mają charakter nieco żartobliwy, ale żart ten (jak każdy dowcip, czego uczy nas Freud) służy autorowi do powiedzenia czegoś o sobie i o dręczących go obsesjach.

Jeszcze jedna reminiscencja zasługuje tu na przywołanie, gdyż łączy się z interesującymi nas kategoriami skalania i analności:

Nie wspominałbym zresztą o tych nocnych lunatyzowaniach, gdyby jedno z nich, bodaj ostatnie, nie skończyło się kompromitującą katastrofą. Stało się to wiosną roku 1923 na statku „Bajka”, podczas parodniowej szkolnej wycieczki do Płocka. Zapewne podróż wodą i w słońcu, a potem zwiedzanie zabytków miasta sprawiły, iż wieczorem poczułem się bardzo zmęczony i ledwie zmierzch zaczął zapadać, zszedłem z pokładu. W kajucie zasnąłem szybko i twardo. A ocknąłem się w scenerii, jakiej w najkoszmarniejszym śnie nie potrafiłbym wyśnić. Gdy zabrakło opiekuńczych ramion matki i jej uspokajającego głosu, poniosły mnie owe niewiadome wewnętrzne fermenty, nieprzytomny wylazłem w nocnej koszuli (pyjamy nie były jeszcze w powszechnym użyciu) na pokład i tam, przykucnąwszy, z r o biłe m $\mathrm{kupę,} \mathrm{w} \mathrm{tej} \mathrm{właśnie} \mathrm{hańbiącej} \mathrm{pozycji} \mathrm{rozbudził} \mathrm{mnie} \mathrm{zbiorowy} \mathrm{rechot.} \mathrm{Powracającego} \mathrm{z} \mathrm{zaświatów}$ i z przerażeniem rozglądającego się wokół zmętniałymi jeszcze oczami otaczali koledzy, i c h w y s o k i e, trochę zdeformowane sylwetki i śmiech osaczały mnie nieszczęsnego, jak zaszczute zwierząt ko, księżyc, bliski pełni, bezwstydnie rozjaśniał mroki. Chciałem uciec, gdzieś się skryć, nie mogłem, zmuszono mnie, abym uprzątnął dowód przestępstwa, ktoś litościwy przyniósł jakiś papier, co było później tej nocy i nazajutrz - nie pamiętam [...]. [...] mogę się tylko po omacku domyślać, iż całe zdarzenie [...] mogło mnie przytłoczyć swoim ciężarem i wyrzucić s a mot nego i napiętnowanego poza orbitę, po której bezpiecznie i beztrosko dotąd krążyłem. Jakkolwiek było i jakikolwiek wpływ na mój dalszy rozwój miała, czy mogła mieć ta historia - moja pa mi ęć sygnalizuje $z$ wiarygodnością docierająca do granic pewności, iż właśnie rok 1923 był pod wieloma względami przełomowym w moim życiu. [N 236-237; podkreśl. W. Ś.]

Historia, która przydarzyła się Andrzejewskiemu, każdego wprawiłaby chyba w konsternację i każdemu zapadłaby w pamięć. Nie ma wątpliwości, że publiczne

17 Nadzwyczajna liczba owadów i robaków przywołuje dwa ciąi skojarzeniowe. Pierwszy jest, oczywiście, trupi - trup stanowi pożywkę dla much i larw; drugi, nie mniej ważny, to motyw sataniczny, wpisujący się w ciag zdarzeń rozpoczętych opacznym „bierzmowaniem” w smole, przemianą stóp w „kopytka”. Bycie żywicielem owadów czyni z narratora „władcę much i komarów” - Belzebuba (nieprzypadkowo, mam wrażenie, Janion w swojej książce Wobec zła umieściła obok siebie szkice o Andrzejewskim i o Wtadcy much W. Goldinga). 
wydalanie jest $\mathrm{w}$ naszej kulturze niewyobrażalnym skandalem ${ }^{18}$. Odczytajmy wszakże tę historię nie jako pojedyncze wspomnienie $z$ młodości, lecz jako element gry brudu i czystości, która prowadzi Andrzejewski we wszystkich niemal utworach składających się na Nowe opowiadania. Defekacja (przestępstwo) wytwarza napięcie między podmiotem („samotnym i napiętnowanym”) a otaczającymi go ludźmi. Kupa (wizualny dowód przestępstwa) musi zniknać, podmiot musi sam ją uprzątnąc - tylko w ten sposób zostanie przywrócony stan pierwotny, niezakłócony, a podmiot odzyska szanse na reintegrację $z$ grupa. Opisane wydarzenie miało najprawdopodobniej decydujący wpływ na jego dalsze życie - mówi nam Andrzejewski i jest to trzecie uogólnienie.

Andrzejewski był homoseksualistą i pomimo małżeństwa - jak zaświadczają znający go ludzie - dość otwarcie do kwestii własnego homoseksualizmu podchodził. Nie zmienia to jednak faktu, że homoseksualność stanowiła dla niego problem na wielu poziomach: społecznym, psychologicznym czy twórczym. W notatkach autobiograficznych zdaje się on sytuować homoseksualność, utożsamianą z brudem i analnością, w obszarze, mówiąc po Bachtinowsku, „dołu materialno-cielesnego”. W błyskotliwym eseju Tomasz Sikora pisze:

Odbyty homoseksualnych mężczyzn to szczególnie gorący temat. Seks analny nieodwracalnie skazuje gejów na brud, może nawet dosłownie na umazanie gównem. Od gejowskich tyłków zdaje się zależeć los rodziny, społeczeństwa, ba, całej cywilizacji. Fascynacja analnością zagraża patriarchalnym konstrukcjom męskości, a zwłaszcza imperatywowi męskiej samokontroli, terytorialnej/cielesnej suwerenności i nienaruszalności ${ }^{19}$.

Klasyczną analize wyobrażonych związków pomiędzy analnością, brudem, homoseksualnością a śmiercią przeprowadza Leo Bersani w eseju Czy odbytnica jest grobem? ${ }^{20}$ Utożsamienie brudu, analności i homoseksualizmu, którego najgłośniejszym wyrazicielem w Polsce jest ostatnio ksiądz Dariusz Oko, stanowi pewien względnie stały element seksualnej wyobraźni Zachodu ${ }^{21}$. Bersani zwraca uwagę m.in. na to:

publiczny dyskurs na temat homoseksualistów jest [...] niepokojąco podobny do reprezentacji prostytutek w XIX w., które przedstawiano jako „naczynia skażenia, przenoszące k obie ce choroby weneryczne na niewinnych mężczyzn [...]"22.

Zob. np. D. Lap orte, History of Shit. Transl. N. Benabid, R. E1-Koury. London 2000, s. $42-44$.

T. Si k o r a, Odmieńcy/śmieci. „Kultura Współczesna” 2007, nr 4, s. 57.

L. B ers a ni, Czy odbytnica jest grobem? Przeł. M. A. Pelczar. W zb.: Teorie wywrotowe. Antologia przekładów. Red. A. Gajewska. Poznań 2012. Wcześniej jeszcze o „rewolucyjności” seksu analnego pisał w Le Désir homosexuel (Paris 1972) G. H o c qu e n g h e m (szerszy przegląd różnych stanowisk oferuje D. M. Pr ov e n c h e r (Queer French. Globalization, Language and Sexual Citizenship in France. Ashgate 2007, s. 72-78)).

21 Wyobrażenia te, intensyfikując się w momencie wybuchu epidemii AIDS, nabrały performatywnej mocy. To niebezpieczne zjawisko zainspirowało Bersaniego do napisania w $1985 \mathrm{r}$. wspomnianego eseju.

Bers ani, op. cit., s. 764 . 
Narrator Notatek do autobiografii (1909-1924) (sam Andrzejewski?) nie postrzega siebie jako zarażonego chorobą weneryczna, ale jako zarobaczonego, podgryzanego przez owsiki i wszy łonowe. Jego ciało karmi te robaki i pasożyty, jakby było martwe - jakby sam był martwy. Nie poddany obrzędowej akulturacji trup, kał i odmieniec (homoseksualista) mają ze sobą wiele wspólnego - przede wszystkim są odpadami:

Trupy są, ni mniej, ni więcej, jak tylko odpadami, które należy pogrzebać. Chrześcijański Zachód z podobnym wstrętem traktuje smród gówna i smród trupa [...]. Zagrożenie kojarzone ze zmarłymi może być uchylone jedynie wówczas, gdy zasada demokratycznej równości zostanie rozszerzona na martwe ciała w takim samym stopniu, w jakim dotyczy żywych. Wybawiony z promiskuitycznej anonimowości masowego grobu trup staje się obiektem kultu. Jako jednostkowy - trup przestaje być cuchnącym odpadem, nabiera godności szczątek; zrywa swoje związki z kloaką i staje się dobrym, nabożnie przechowywanym ekskrementem ${ }^{23}$.

„Kobiety i geje rozkładają nogi z nienasyconym apetytem na destrukcję”. Taki homoseksualista „nie jest w stanie odmówić sobie samobójczej ekstazy bycia kobietą"24. Skąd ta samobójczość? Bersani dowodzi - przywołując m.in. prace Michela Foucaulta, Johna Boswella i pośrednio Kennetha J. Dovera - że nawet w kulturach, które akceptują zachowania homoerotyczne, granica akceptacji jest receptywność: „istnieje prawna i moralna niekompatybilność seksualnej pasywności i autorytetu obywatelskiego”, „Pozwolić się penetrować oznacza zrzec się władzy”25. Pasywność świadczy o roztopieniu się podmiotu w seksualnej (i tanatycznej) jouissance (rozkosz, ekstaza); dominuje przekonanie, że „oznaczający samozniszczenie seks analny jest zasadniczo i pierwotnie utożsamiany z fantazmatycznym misterium niezaspokojonej, niepowstrzymanej kobiecej seksualności” - dlatego, jak głosi tytuł eseju Bersaniego, „odbyt jest grobem” męskiego podmiotu, a seks analny budzi wstręt, który Julia Kristeva diagnozuje jako coś, co wprawdzie „wyznacza podmiot, lecz nie oddziela go radykalnie od tego, co mu zagraża, przeciwnie - ujawnia, że podmiot jest w ciagłym niebezpieczeństwie" 26 .

W podejściu do homoerotyzmu u Andrzejewskiego internalizacja kulturowych stereotypów i lęków, z jaką mamy do czynienia w przypadku jego twórczości, bywa przełamywana przez inne sposoby kodowania nienormatywnego pożądania ${ }^{27}$. Wydaje się, iż właśnie internalizacja tych kulturowych przekonań, w jakich homoerotyzm łączy się z masochizmem, nieczystością i śmiercią, stanowi uczuciową dominantę wielu utworów autora Bram raju. Jej wyrazem sa powracające (znowu chciałoby się powiedzieć: persewerowane) motywy skatologiczne.

La porte, op. cit., s. 74. Zob. też J. Kristeva, Potęga obrzydzenia. Esej o wstręcie. Przeł. M. F als ki. Kraków 2007, s. 103: „Gnijące ciało, pozbawione życia, całkowicie staje się nieczystością, przejściowe kłębowisko, dwuznaczny element między tym, co zwierzęce, a tym, co nieorganiczne, [...] trup to fundamentalne zanieczyszczenie".

Bersani, op. cit., s. 765 .

Ibidem, s. 766.

Kristeva, op. cit., s. 15.

Przypomnijmy np., że utwór Przed sądem jest uwzniośleniem niewypowiadalnego pożądania (formuła G. Ritza) i należy do najpiękniejszych w polskiej, a być może i światowej literaturze. Szerzej o różnych pryzmatach więzi jednopłciowych u Andrzejewskiego piszę w nadmienionym tu już szkicu Kawatek tortu Fedora. 
Jeśliby szukać krótkich, hasłowych formuł porządkujących podejście najważniejszych pisarzy polskiego modernizmu do homoseksualizmu, można by stwierdzić, że dla Iwaszkiewicza jest to sublimacja, dla Gombrowicza intelektualizacja (a więc również pewna forma sublimacji), dla Andrzejewskiego zaś - odmowa sublimacji. Odmowa ta ma dalekosiężne skutki - odmieniec staje się trupem na gnojowisku analogicznie do Maćka Chełmickiego, który nie zatrzymuje się na komendę wojskowego patrolu:

Podobnie jak odpady, seksualna „odmienność” jest „nieodłącznym efektem społecznie opłacalnej produkcji”, a raczej reprodukcji, i wymaga się od niej „wzbogacenia cywilizacji poprzez sublimację”. System społeczny produkuje odmieńca w tym samym stopniu co heteroseksualistę, choć w mniej oczywisty sposób. Postrzegany jako społecznie „bezproduktywny” odmieniec (obowiązkowo wyobcowany i nieszczęśliwy) ma dowieść swojej wartości poprzez wzmożoną sublimację, przez jakieś cenne dokonania artystyczne lub intelektualne, przez zaangażowanie się w działalność społeczną ${ }^{28}$.

Uprawianie literatury, analogicznie do uprawiania każdej innej sztuki, czy szerzej mówiąc - wszelka aktywność pożądana z punktu widzenia społecznego jest już sama w sobie czynnością o charakterze sublimacyjnym, pozwalającą na przynajmniej częściowe odkupienie odmieńczych win. Formułując myśl o odmowie sublimacji, muszę ją zatem doprecyzować. Sięgam w tym celu do Miłosza:

Im więcej martwił się swoim nieuporządkowanym życiem, tym bardziej cenił czynność odkupiająca, jaką było dla niego pisanie, i tym bardziej nadawał jej wagę uroczystego obrządku ${ }^{29}$.

Komentarz Miłosza dotyczy funkcji, jaką uprawianie literatury spełniało dla samego Andrzejewskiego. Pisanie, krótko mówiąc, miało być dla niego zbawcze, nadawać sens - to już moje dopowiedzenie - odmieńczej egzystencji. W tym znaczeniu więc było jak najbardziej sublimacyjne ${ }^{30}$. Opinię Miłosza dobitnie potwierdza obserwacja innego spośród przyjaciół Andrzejewskiego - Zygmunta Mycielskiego:

Pisze o sobie, oczywiście. Marysia [tj. żona Andrzejewskiego] widzi w nim potwora, erotomana, alkoholika - to wszystko prawda. Jerzy w domu - to potwór. Co z takim robić? A on myśli tylko o wartości tego, co pisze, niepokoi się, czy to nie grafomania, pije, bełkocze i chwyta się nagich chłopaków, chce utrzymać, złapać młodośćc ${ }^{31}$.

Odmowa sublimacji dotyczy tego, co Andrzejewski p i s ze, a nie tego, że pi s z e, bo pisanie samo w sobie ma już charakter sublimacyjny. W tej części swoich rozważań chciałbym skupić się na dwu sprawach: na funkcji p i s a ni a jako sublimacji, a następnie na tematyzowanej w tym, co Andrzejewski pis ze, odmowie sublimacji, która wyraża się w - ro z pis a n ej na różne postaci - degradacji cielesności pożądającego podmiotu.

Fragment Mszy za poetę, dzięki podwójnemu ulokowaniu publikacyjnemu, jest zarazem utworem Adama Nagórskiego (w Miazdze), jak i samego Andrzejewskiego (w Nowych opowiadaniach, a wcześniej - bezdebitowo - w „Zapisie”). Kroki boha- 
tera utworu osnutego wokół autentycznego wydarzenia z życia Andrzejewskiego (udział we mszy za duszę Kazimierza Wierzyńskiego 11 III 1969) prowadzą do knajpy znanej z młodości:

Dokoła, na ławie otaczającej stoły, na podostawianych stołkach, przy kominku, wokół kontuaru i w cieniu spiętrzonych pod oknem skrzyń, a także na ciasnej, wolnej przestrzeni pośrodku tłoczyli się sami młodzi, chłopcy przeważnie, rozgrzani i hałaśliwi, brzydcy, nijacy i ładni, ubrani niedbale, ubogo i kolorowo, z baczkami i bez, schludni i rozkudłani, niektórzy jeszcze trzeźwi, w większości podpici i pijani, ale wszyscy młodzi, nieprzyzwoicie młodzi, dwudziestoletni, i ta młodość, chociaż z pewnością już u niejednego dotkliwie nadszarpnięta, biła jak oślepiający blask $\mathrm{z}$ ich zaczerwienionych i spoconych twarzy, i z ich zdrowych młodych ciał, z młodych ruchów i z młodych głosów, i ja ze swoją sześćdziesiątką w skórze, we włosach, w paznokciach i w sztucznych zębach, musiałem się wstydzić swego więdnacego ciała, byłem tu cieleśnie obcy i niepotrzebny, jakby zinnego, piwnicznego świata, gdzie obowiązują całkiem odmienne reguły współżycia i obyczaje, choć równocześnie zdawałem sobie sprawę, że wielu spośród tych chłopców należy do moich czytelników, a - być może - niejeden z nich lubi moje książki i czułby się zaszczycony, a także onieśmielony, gdyby miał okazje osobiście mnie poznać ${ }^{32}$.

Starzejący się Andrzejewski/Nagórski wciąż pragnie zawsze być atrakcyjny fizycznie, ale pozostaje mu wstyd wobec olśniewającego blasku młodości. Nagórski dla tych młodych nie będzie kimś takim, jakim dla niego był ojczym-pułkownik, przystojny ułan-piłsudczyk, dzięki któremu (poprzez którego) pokochał literaturę:

Owszem, w roku 1924, z okazji sprowadzenia do Warszawy zwłok Henryka Sienkiewicza, wygłosiłem na naszej szkolnej akademii odpowiedni referat, podejrzewam jednak, iż namiętność, z jaką zanurzyłem się w świat bitew i przygód, w większym stopniu kierowana była moimi skłonnościami ku osobie rycerskiego ojczyma niż rzeczywistym zainteresowaniem literaturą ${ }^{33}$.

Jego ciało jest ciałem-odpadem, które nie może zostać włączone w łańcuch pragnienia. W sukurs przychodzi proteza literackości - Nagórski/Andrzejewski fantazjuje o możliwości onieśmielenia zajętych sobą młodych chłopców poprzez ujawnienie siebie jako pisarza. Wyobrażenie o atrakcyjności tej roli towarzyszy Andrzejewskiemu konsekwentnie od samego początku drogi twórczej. Nie celebra i uroczystość pisarstwa, nie „czynność odkupiająca”, ale właśnie jego swoisty seksapil, jego sublimowanie cielesności, przekraczanie jej niedostatków, jego erotyczność stanowią najgłębszą treść pisarstwa dla Andrzejewskiego. Przeżycie starego Nagórskiego jest tylko odbiciem przeżycia bohatera Notatek do autobiografii (19091924). Rok po nieszczęsnym epizodzie na pokładzie wiślanego statku ${ }^{34}$ 15-letni chłopiec przechodzi transformację pod wpływem doświadczeń osobistych i przeczytanych lektur:

I tak oto bardzo do tej pory pogodny, towarzyski i wesoły, zawsze dla kolegów otwarty - stałem się osobnikiem stroniącym od klasowej zbiorowości, nadmiernie uwrażliwionym i wstydliwym, uczniem przeciętnym, w sensie sprawności fizycznej: niedołęga. Nauczyciel gimnastyki [...] nigdy nie mógł mi darować, że z jego ulubieńca, bo jednego z najlepszych w klasie sportowców, stoczyłem się do kondycji ofermy partaczącej w koszykówce i niezmiennie obtłukującej pośladkami kozła do skoków. [...] Lecz

J. Andrzejewski, Miazga. Oprac. A. Synoradzka-Demadre. Wrocław 2002, s. 624-625. BN I 305. Podkreśl. W. Ś.

33 Ibidem, s. 475.

34 A więc w r. 1924, gdy Nagórski odkrył literaturę jako medium zbliżenia z ojczymem. 
jakże pisarzowi wypadało skakać przez przeklętego kozła? Więc też od kiedy opuściły mnie zręczności i lotność ruchów oraz sprawność mięśni - począłem pogardzać dobrą formą fizyczną... [N 264]

Celowa i zapewne nieco teatralna w wyrazie rezygnacja $\mathrm{z}$ przywilejów, jakie gwarantuje dobra forma fizyczna, służy stworzeniu pożądanej - w wyobrażeniu Andrzejewskiego - kreacji pisarskiej. Ta ostatnia wszakże nie oznacza całkowitego wyłączenia się z grupy rówieśniczej, chodzi raczej o zmianę wizerunkową, młody Andrzejewski dzięki odrzuceniu ,fizkultury” buduje inny, nowy kragg znajomych:

Nie stałem sie jednak odludkiem i mizantropem, towarzystwa rówieśników nadal potrzebowałem, tyle tylko iż rozluźniły się moje przyjaźnie dotychczasowe, a zawiązywać poczęły nowe, tym się przede wszystkim charakteryzujące, iż już nie były u początku wynikiem sympatii obustronnej, również te przyjaźnie nie ja wybierałem. Nie przypadek sprawił, że gdy z pewną ostentacją oddalałem się od prowadzących w klasie rej - szukać mego towarzystwa oraz przyjaźni poczęli ci, którzy z racji swych dziwactw, pokręceń i śmiesznostek od dawna istnieli na marginesie koleżeńskiej wspólnoty, bez protestu dzieląc pomiędzy sobą ciężki los tych gorszych. [N 265]

Cytowane fragmenty przedstawiaja perspektywę, oczywiście, dojrzałego twórcy, ale, jak widać w przywołanym nieco wcześniej fragmencie Miazgi, to przekonanie o nieubłaganym konflikcie „prostackiej” fizycznej atrakcyjności i bardziej wysublimowanych pisarskich powabów powraca (trwa) także w wieku dojrzałym, lecz nie towarzyszy mu już raczej pewność, która towarzyszyła młodzieńczemu wyborowi - oto bowiem tym, co pisarza zajmuje coraz bardziej w miarę upływu lat, jest, tracące swoje kolejne erotyczne powaby, starzejące się ciało. Procesowi temu nie może zaradzić nawet najlepsza „literacka proteza”.

Wnikliwy czytelnik Andrzejewskiego, Nowacki, zauważa: „Dyskurs ten [tj. dyskurs ciała] tym intensywniej daje o sobie znać, im z późniejszymi tekstami Andrzejewskiego mamy do czynienia [...]"35, i omawia pod tym katem trzy ostatnie opowieści autora Miazgi ze szczególnym uwzględnieniem relacji młodość-starość (za Janion śledzi on motyw wampiryzowania młodości). Wydaje się wszakże, iż problem leży nie w tyle w generacyjności, ile raczej w tym, że ciało tego, kto pożąda, zawsze jest ciałem szpetnym, naznaczonym, niechcianym. Problem ten pojawia się właściwie na samym początku drogi pisarskiej Andrzejewskiego, a starość jedynie go wyostrza. Aby zilustrować to twierdzenie, proponuję wrócić do jego debiutanckiej powieści Ład serca.

We wspomnianym utworze da się dostrzec - w całej polifonii wątków - element Bildungsroman, gdyż Michaś, podopieczny księdza Siechenia, w trakcie opowieści wyrasta na pisarza. Zanim wszakże to się stanie, Michaś musi przejść pewien rodzaj inicjacji „uwalnia się spod logosu ojca - przestaje się modlić [....”"36. Tyle jedynie że tym ojcem, ojcem zastępczym, jest ksiądz Siecheń. Większość dotychczasowych odczytań powieści dość wiernie pozwalała się prowadzić autorowi i odtwarzała historię nawrócenia Siechenia jako odrzucenie Anny i „miłości ziemskiej” w imię sublimacji i „miłości niebiańskiej”, kapłańskiego powołania. Ale sprawa wydaje się

36 G. Ritz, Jerzy Andrzejewski: maski pożadania i ich funkcja $w$ poetyce powieści. Przeł. A. Kopa cki. W: Nić w labiryncie pożądania. Gender i płeć $w$ literaturze polskiej od romantyzmu do postmodernizmu. Warszawa 2002, s. 222. 
nieco bardziej skomplikowana - ksiądz Siecheń, mężczyzna dojrzały, choć z pewnością nie stary, pozostaje nadzwyczaj wrażliwy na cielesne podniety ${ }^{37}$. W jednej z pierwszych powieściowych scen konfrontuje swoją cielesność $z$ wyzwolonym, pięknym ciałem Siemiona Dubrowskiego. German Ritz twierdzi, że w nadrzecznej scenie kapieli „ksiądz Siecheń odczuwa własną bezcielesność” ${ }^{38}$. Nic bardziej błędnego - można odnieść wrażenie, iż Siecheń szczególnie mocno doświadcza właśnie swojej cielesności:

Pozbawiony sutanny, wydany na jaskrawe światło słońca, które okrutnie podkreślało wąłość wychudłego ciała, czuł się śmieszny, niedorzecznie odcinający od bujności traw i nadbrzeżnych trzcin. Jak żałośnie musiał wyglądać z tą swoją klatka piersiową niekształtnie sklepioną, ramionami wyprutymi z muskułów. Tymczasem Siemion wolno schodził ku rzece. [...] Ksiądz Siecheń przeżył kilka okropnych chwil. Bał się spojrzeć w oczy Siemiona, aby nie dojrzeć w nich, jak przypuszczał, ironicznego lub pobłażliwego błysku. [Ł 15; podkreśl. W. Ś.]

Siecheń, zagadnięty przez Siemiona, próbuje przedstawić zbieg wydarzeń, który sprowadził go nad rzekę:

Zarówno ustronne miejsce, jak i pora obiadowa zdawały się zapewniać samotność. Ściagnął sutannę, szybko się rozebrał. Słońce mocno przygrzewało, ale jakaż rozkosz czuć jego ciepło na skórze nieskrępowanej żadną odzieżą! Położysz się na ziemi - niebo zobaczysz przechylone nad sobą, orzeźwiający chłód cię ogarnie, brzęk owadów otoczy... Ale tego wszystkiego, choć chciał, nie wypowiedział wobec Siemiona. To $z$ dalszych słów tamtego wytrysnęło, niby snop iskier, zachwycenie swobodą. Radosne zapamiętanie, zdobywcza chłonność. Proboszcz słuchał oszołomiony. Czemuż sam nie umiał się tak radować? Cierpiał. [Ł 16]

Ritz omawiając Adama Grywałda Tadeusza Brezy wskazywał, iż autor ten zaczerpną zdarzenie $\mathrm{z}$ pomocnikiem krawieckim bezpośrednio $\mathrm{z}$ utworu Marcela Prousta ${ }^{39}$. Stawiam tezę, że opis przeżyć księdza Siechenia jest zapożyczeniem kluczowej sceny z Immoralisty André Gide'a ${ }^{40}$; sceny, w której dokonuje się przemiana duchowa tytułowego bohatera tej powieści, Michała:

Pewnego dnia, obnażywszy sie całkowicie, przyjrzałem się sobie dokładnie; widok zbyt chudych rąk, ramion, których największym nawet wysiłkiem nie mogłem odrzucić w tył, zwłaszcza jednak biel, a właściwie odbarwienie skóry napełniły mnie wstydem i wycisnęły łzy. Ubrałem się szybko i, zamiast zejść jak zwykle do Amalfi, skierowałem się ku skałom [...], wiedziałem, że mnie tu nikt nie zobaczy.

Komentujący - niechętnie - powieść A. S a n d a u e r (Szkoła nierzeczywistości i jej uczeń. W: Bez taryfy ulgowej. Kraków 1974, s. 45) mówi wręcz o tym, że wiara nie jest Siecheniowi dana, że stanowi raczej cel jego dążeń, ambitne zadanie, które on przed sobą stawia, a powieść, cała bazująca na schematach literatury popularnej (Zarzycka, Mniszkówna), została „zaprawiona neokatolicka głębią".

39 G. Rit z, Iwaszkiewicz, Breza, Mach: niewypowiadalne pożadanie a poetyka narracji. Przeł. A. Kopa cki. W: Nić w labiryncie pożadania, s. 188.

40 Ład serca, oczywiście, co szybko zidentyfikowała krytyka, nawiązuje do modnej wówczas francuskiej powieści katolickiej (G. Bernanos, F. Mauriac), toteż odniesienie się do A. Gide’a, który wobec tego nurtu sytuował się jak najdalej, ma charakter pokrętny - Andrzejewski odwraca wektory aksjologiczne wyznaczające kierunek rozwoju fabuły Immoralisty. O relacjach Gide'a i Mauriaca zob. J. L. Ba r ré, François Mauriac. Biographie intime 1885-1940. Paris 2009. 
Doszedłszy na miejsce, rozebrałem się powoli. Powietrze było ostre, ale słońce paliło. Wystawiłem ciało na jego promienie [...]. Czułem pod sobą twardą ziemię; muskały mnie chylące się trawy ${ }^{41}$.

Doświadczenie własnego ciała ostatecznie przemienia bohatera Gide’a - z zamkniętego w sobie anemicznego naukowca staje się on immoralistą, który poddaje się popędom ciała, formuje je dzięki słońcu i ćwiczeniom fizycznym. Jest gotów poświęcić zdrowie i życie swojej żony, byle napawać się towarzystwem berberyjskich młodzieńców. Analogiczne doświadczenie księdza Siechenia stanowi jednorazowy wybryk - niespodziewana konfrontacja z Siemionem sprawia, iż Siecheń wbije się na powrót w sutannę niczym ślimak w swoją muszlę, pozostanie niechętny własnemu ciału, będzie się go wstydził. Dodajmy, że drugi bohater sceny, gajowy Siemion Dubrowski, rywalizuje w duszy Michasia z księdzem Siecheniem o pierwszeństwo. Wychowywany na plebanii chłopiec ucieka księdzu do lasu, gdzie spędza czas wspólnie z młodym gajowym, którego (inaczej niż samotnego proboszcza) „wszyscy kochaja” ( $($ 17) i który - w tajemnicy, także przed księdzem, uratował Michasia z topieli („Taki cudowny był wtedy! Okrył mnie swoją kurtką. Potem aż do samych Sedelnik odprowadził" - wyznaje proboszczowi Michaś 〈Ł 18〉).

Język rozważań księdza Siechenia, choć osadzony w języku religijnym i nasycony biblijnymi skojarzeniami (Siemon „wślizgujący się” w rajską harmonię dotychczas panującą między proboszczem a jego podopiecznym), wydaje się niepokojąco bliski języka miłości ziemskiej i zmysłowej, języka zdradzonego kochanka. Po usłyszeniu historii uratowania niedoszłego topielca:

Zdał sobie sprawę [Siecheń], że serce małego nie należało już do niego wyłącznie. [...] Oto nawet nie wiedział, kiedy przyszła chwila, w której na życie Michasia, dotąd tak proste i jawne, padł zaborczy cień, aby mógł pod jego osłoną wśliznąc się ktoś nowy. [...] Ksiądz Siecheń czuł, że teraz z każdym dniem Michaś będzie się od niego oddalał. Aż przyjdzie chwila, gdy odejdzie zupełnie. [Ł 18]

Bliskość emocjonalna między opiekunem a umykającym mu podopiecznym jest istotnie zdumiewająca, przeszłość zaś Siechenia kryje nie tylko romans z Anną, ale także - nader zażyła - męską przyjaźń:

Uderzony tym przejmującym akcentem [tj. okrzykiem Michasia - „Może już nie żyje!” - na wspomnienie rannego Siemiona] ksiądz Siecheń przypomniał sobie, że przed wieloma laty, w czasie wojny, gdy wśród ciemnej nocy odnalazł na polu ciężko rannego przyjaciela, podobny okrzyk i jemu się wyrwał. Głęboko w świadomości, jakby uśpione, lecz niezmienne, gdy ocknie się nagle, odnalazł przerażenie. [Ł 20] $]^{42}$

Noc, która w powieści przynosi ze sobą tyle zdarzeń, konfrontuje, rzecz jasna, Siechenia z Anną, ale wcześniej konfrontuje go z samym sobą i z Michasiem. Oto bowiem Michaś wymknął się wieczorem z plebanii do gajówki, gdzie umiera ranny Siemion. Jego przedłużająca się nieobecność skłania zaniepokojonego księdza do wyjścia i poszukiwań, lecz w ostatniej chwili Michaś wraca. Ksiądz, mimo iż ma pełne prawo zbesztać 14-latka, otacza go opieką - rozpaczliwą w świetle fascynacji

41 A. Gide, Immoralista i inne utwory. Przeł. I. Rogozińs ka. Wstęp L. Budrecki. Warszawa 1984, s. 324.

42 Namiętny poszukiwacz cudzego słowa niechybnie skojarzy wspomnienie Siechenia ze snem o żołnierzu Wiktora Rubena z Panien z Wilka J. Iwaszkiewicza. 
Michasia Siemionem. Dzięki krzątaninie wokół chłopca powracają na chwilę czasy sprzed „wśliźnięcia się” Siemiona:

Widząc, że zziębniętemu z trudem przychodzi poruszanie, zaczął mu pomagać. Ściągnął z ramion kurtkę nasiąkłą deszczem, rozpinał mokrą zupełnie koszulę.

Michaś nie protestował. Był znowu dzieckiem bezradnym i powolnym. Bez jednego słowa poddawał się pośpiesznym ruchom opiekuna. Wyglądał tak żałośnie, że ksiądz Siecheń nie miał serca robić mu wyrzutów. O nic chwilowo nie pytał. Ułożywszy go w łóżku, poszedł do kuchni postawić wodę na herbatę. [t 24]

Scena rodzicielskiej czułości zostaje przesycona jednak cielesnością i erotyka, gdy stopniowo obnaża się ciało młodzieńca, które jest tyleż jędrne, ile powolne pragnieniu opiekuna (powolność nagiego ciała wydaje się rekompensatą za samodzielność skrytej duszy). Scena ta, co okazuje się trochę dalej, stanowi również sprawdzian powściagliwości księdza, który tego samego wieczoru wyznaje:

Nie, grzeszyć, to mogę, lecz nie chcieć grzechu, tego nie mogę. Moje czyny mogą świadczyć przed ludźmi za mną, lecz moje myśli oskarżą mnie przed Tobą. I choćbym nie grzeszył, będę grzeszny. Jestem skażony. Nawet źródłem moich dobrych uczynków jest moje zło. [Ł 30-31]

\section{A nieco później:}

Panie, nie mam miłości! Moje dłonie są dłońmi zbrodniarza, moje usta mają wargi krzywoprzysięzcy, oszukuję, kłamię, nienawidzę, żadna rozpusta nie jest mi obca, moje myśli zatruwa brudne pożądanie, znam godziny wyuzdanej maligny, pycha mnie oślepia i zazdrość, i pogarda, i fałszywa miłość siebie. [Ł 41]

Nieszczęśliwy, retorycznie nieznośny i koturnowy w swoich rozmowach z Bogiem ksiądz Siecheń tym różni się od swoich następców: Torquemady, hrabiego Ludwika czy nawet Szczuki z Ortizem, iż pozbawiony jest ich charyzmy, a pozbawiony jej, nie może stać się przywódcą. Tragizm księdza polega na tym, że nikt za nim nie podąży. Najbliżej mu w tym do spowiednika $z$ Bram raju (autor pisał je w okresie, kiedy - według świadectwa Szymańskiej - zaczął odczuwać przedwczesne starzenie się):

sam pełen mrocznych pragnień, w tym tylko celu stanąłem naprzeciw pochodowi młodości, aby siebie w wyznaniach odnaleźć i siebie cudzymi pragnieniami jeszcze raz i może już ostatni raz przywołać do stanu radosnego oddania $[\ldots]^{43}$.

Pragnienia, które dręczą Siechenia, są podwójnie zakazane: homoseksualnie i incestalnie, ale to właśnie fakt, że jego ciało jest tak odpychające i nieatrakcyjne, przypieczętowuje jego klęskę, Siecheń musi zamilknąć: „Nabożeństwo potoczyło się w ciszy, prawie bezgłośnie, przerywane tylko żałosnym dźwiękiem srebrnego dzwonka. Każde słowo sprawiało księdzu Siecheniowi ból” (Ł 261). Natomiast wyzwolenie się z niezdrowego układu ma ozdrowieńczy wpływ na Michasia, który zaczyna pisać - katartyczna czynność przywraca go niejako społeczeństwu, ustanawia jego użyteczność socjalną. 
Podsumowując, przywołajmy komentarz Antka Raszewskiego z kart Miazgi. Jak wiadomo, Andrzejewski wplótł ów komentarz napisany przez Antoniego Liberę w misterną kompozycję utworu m.in. po to, by jeszcze bardziej rozbudować i skomplikować więź między bohaterem (Adam Nagórski) a autorem (Jerzy Andrzejewski) $^{44}$ :

Niechęć do siebie, owa choroba pogardy dla samego siebie stanie się wkrótce całym mechanizmem, swoiście masochistycznym: im bardziej odbiegnę od siebie takiego, jakim bym siebie pragną, tym zwiększę w przyszłości własną inwencję; im więcej będę cierpiał ze swego powodu, tym lepiej. Dlatego też historia twórczości Nagórskiego jest w istocie historią wznoszenia się przez upadki ${ }^{45}$.

W eseju Raszewskiego te cechy osobowościowe: niechęć do siebie i pogarda Nagórskiego dla samego siebie (a poprzez niego i do Andrzejewskiego), rzutowane są na bohaterów jego prozy i ich cielesność - taki np. okazuje się Hermann Euler (Eisberger $\mathrm{z}$ utworu Już prawie nic).

W hotelu, mając jeszcze godzinę czasu, bierze kąpiel, jest więc zmuszony widzieć swą nagość. Szczególną uwagę zwraca na paznokcie i skórę, ,jest stara - myśli - wygląda jak zwiotczała szmata"46.

Tomasz Kaliściak przekonująco dowodził, że homoseksualni poeci (Józef Czechowicz, Stanisław Swen-Czachorowski czy Stefan Napierski, zaprzyjaźniony z Andrzejewskim) tworza „poetyckie kontinuum, nie tyle homoseksualne - ile homospołeczne”47, a „podmiotowość każdego odmieńca zasadza się w istocie na psychotycznym odrzuceniu opresjonującego porządku"48. Kaliściak odtwarza pewne konstytuanty „wyobraźni katastroficznej”, o której twierdzi, że ona „wykazuje zadziwiająco bliską zależność wobec mechanizmów homofobii”, a „katastrofizm należy interpretować w połączeniu $z$ ekonomią libidinalną, a szczególnie $z$ dominującym popędem śmierci, zmierzającym do destrukcji” 49 .

Andrzejewski nie jest katastrofistą w historycznoliterackim znaczeniu tego słowa, ale odmowa sublimacji w połączeniu $z$ ambiwalencja postaw wobec homoseksualności (wieczne wahanie między internalizacją homofobicznych kategorii a pragnieniem emancypacji) sprawia, że i wyobraźnia pisarza wykazuje się predylekcją do ujęć katastroficznych - tym, co ją wyróżnia, jest to, iż katastrofa na ogół dotyczy własnego ciała lub ciał bohaterów, którzy pożądają, których obdarza Andrzejewski, mniej czy bardziej pośrednio, elementami swojego charakteru bądź biografii. Katastrofa ciała, dodajmy, jawi się jako fundament imaginacji katastroficznej w ogóle - wszak wyobrażeń odnoszących się do własnego ciała dotyczyła katastrofa Daniela Paula Schrebera, o której Kaliściak sądzi, iż można z niej wywieść przesłanki do interpretacji twórczości wybranych przez niego autorów ${ }^{50}$. 
Abstract

WOJCIECH ŚMIEJA University of Silesia, Katowice

JERZY ANDRZEJEWSKI - CATASTROPHES OF BODY AND REJECTION OF SUBLIMATION

The article focuses on an analysis of Jerzy Andrzejewski's strategy of presenting his own corporality with careful attention directed to his autobiographical texts: Notatki do autobiografii (1909-1924) (Notes to autobiography 〈1909-1924〉) and also to the writer's literary creativity - inter alia to Ład serca (Mode of the Heart) and Miazga (Pulp). The body is marked with a "non-normative" desire, and as such becomes the undesirable body. Due to the expression of the desire of sexual receptivity the body falls beyond the order of presentation; it can only be recognised as corpse - repugnant, masochistic, eaten by worms when still alive. Such body, failing to yield the modernist sublimation, becomes a "catastrophic body." 